\title{
The Implementation of Online Single Submission (OSS) Program in the Capital Investment and One- Stop Integrated Services Agency in Bantul Regency
}

\author{
Ardiyati $^{1}$ \\ \{ardiyati@amikom.ac.id ${ }^{1}$ \} \\ AMIKOM Yogyakarta University, Indonesia ${ }^{1}$
}

\begin{abstract}
The Online Single Submission (OSS) program is business licenses which is given in behalf of government institution, governor, or mayor for business by integrated electronic and online system in accordance with Presidential Decree Number 91 Year 2017 and Government Regulation N0. 24 Year 2018. This study aims to determine how OSS policy is implemented in Capital Investment and One-Stop Integrated Services Agency in Bantul Regency. There is a function division of the licensing process in the OSS system. The OSS system processes the registration of business licenses, issuing business licenses and commercial / operational licenses. The capital investment and one stop integrated services agency processes to fulfill commitments or compliance with permit requirements needed in the process of issuing business and commercial / operational licenses. The issuance of a Single Business Number before fulfilling the commitment can bring up various kinds of problems. Therefore, it is important to have a business monitoring regarding a business license number that has not yet fulfilled commitments so that it would not create an impact to the society.
\end{abstract}

Keywords: Implementation, E-Government, Permit.

\section{Introduction}

Licensing services are one of the licenses of the form of public services carried out by the government. They are run by integrated licensing services in regency and cities in Indonesia. Law of the Republic Indonesia No. 25 Year 2009 concerning public services is the basis for the implementation of public services expected by the government in obtaining better public services as follows:

a. Realization of boundaries and clear relationships regarding the rights, responsibilities, obligations and authorities of all parties related to the implementation of public services.

b. Realization of public services in accordance with the principles

c. Fulfillment of the implementation of public services with laws and regulations

d. Realization of legal protection and public certainty in the implementation of public services.

One of the problems occurred in the society when accessing licensing services is an obscurity information, illegal fees, uncertainty and long services, complicated requirements, and etc. This condition encourages the government to bring up one-stop integrated service program. The implementation of integrated services is formed based on Circular Letter of the Minister of Home Affairs No. 503/125/PUOD dated January 16, 1997 concerning establishment of One- 
Stop Integrated Services and the instruction of Minister of Home Affairs Number 25 Year 1998 concerning One-Stop Integrated Services. The form of one-stop integrated services has changed into one door with the legal basis of Minister of Home Affairs Regulation Number 24 Year 2006 concerning the Guidelines for Implementing One-Stop Integrated Services (PTSP). The Minister of Home Affairs Regulation Number 100 Year 2016 concerning Nomenclature Guidelines for the Capital Investment and One-Stop Integrated Services Agency encourages regional governments to change the institutional nomenclature of one-stop integrated services. Then, the Institutional Nomenclature changed to the Capital Investment and One-Stop Integrated Services Agency with the legal basis of Regulation of the Regent of Bantul Number 123 Year 2016 concerning Position, Organizational Structure, Tasks, Functions, and Work Procedures of the Capital Investment and One-Stop Integrated Service Agency of Bantul Regency.

In line with the changes in the institutional licensing of Bantul Regency, ICT devices have been applied to assist licensing services. The implementation of e-government in licensing services is the result of collaboration with the Bantul Regency Government. The study shows that Bantul Investment and One-Stop Integrated Services Agency has applied sub domain online licensing to deliver information and facilitate people seeking for licensing services [1]. The use of information systems in online licensing services that were initially local became nationally integrated. This is in accordance with the policy of Accelerating Business Implementation through Presidential Regulation Number 91 Year 2017 and Government Regulation Number 24 Year 2018 [2]. The policy regulates the efforts to accelerate business licensing services through the application of an Integrated Electronic Licensing Service System (Online Single Submission / OSS).

\section{Research Methods}

This study uses a descriptive qualitative method. According to Kirk and Miller, a qualitative research is a certain tradition in the social science which is fundamentally dependent on human observation in its language in its terminology [3]. According to Suharsimi, a descriptive research is a research intended to collect information about indication status happens, that is the indication based on the real situation when the research is being done. The descriptive research is not intended to observe a certain hypotheses but only describes what it is about something variable, indication, condition [4].

\section{Results and Discussion}

\subsection{The Concept of Public Policy Implementation}

Preessman and Wildavsky define that the concept of implementation is to implement policies to fulfill those stated in policy documents in producing output stated in policy objectives, to complete the mission stated in policy objectives [5]. According to Ripley and Frangklin (1982), policy implementation is the result from the stipulation of laws that provide program authority, policies, benefits / benefits and output [6].

\subsection{The Concept of E-Government}


E-government is a pattern of modern interaction as a consequence of the development of information technology as a means in doing communication. The World Bank group defines that E-government relates to the use of information technology (such as wide area networks, internet and mobile computing) by government organizations that have the ability to create relationships with citizens, businesses and other organizations in government [6 ] Meanwhile, according to Clay G. Wescott, the electronic government is the use of communication and information providing more effective and efficient way in government services, to facilitate public access to information and as a form of government accountability to the public [7], [8].

Some definitions of e-government above emphasize that the use of e-government is as an information technology that can be used by the government to establish relationships with communities, businesses and other organizations in the government. The Electronic Government is also one of the tools in doing communication so that the government can provide effective, efficient, transparent and accountable public services in accordance with the principles of good governance.

The implementation of E-Government is still experiencing various obstacles. Sosiawan (2008) found that there are 465 regencies or cities in Indonesia that had websites in the amount of 194 or 42 percent. From the total amount of websites, there are 186 or 96 percent which can be opened, 8 or 4 percent cannot be opened, and even, there are 271 or 58 percent do not have a local government web. In additions, there are some factors that caused stagnation and less optimal implementation of e-government in Indonesia as follows (1) unclear rules and guidelines regarding technical and operational guidance, (2) lack of human resources in terms of skill and managerial, (3) inadequate infrastructure because of the uneven distribution of the hardware market and information and communication technology service providers, (4) the uneven distribution of community literacy related to the use of e-government [9].

\subsection{Online Single Submission Program (OSS) Concept}

The policy on Online Single Submission (OSS) emerged with the Presidential Regulation Number 91 Year 2017 concerning the Acceleration of Business Implementation and Government Regulation Number 24 Year 2018 concerning Electronic Integrated Business Licensing Services [2]. OSS policy is created as one of the government's policies to accelerate licensing services to work with the Online Single Submission (OSS) Concept. Business licensing is registration or licensing given to business actors to start running a business in the form of letters or decisions or fulfillment of requirements or commitments. Electronic Integrated Business Licensing Services or Online Single Submissions (OSS) is issued by the OSS Institution on behalf of the Minister, Head of Institution, Governor or Regent or Mayor.

Adhering to the OSS concept, business licensing is simplified by the issuance of the identity of the business actor called the Business Registration Number (NIB), the issuance of business licenses and commercial or operational licenses. The concept of an online licensing service system through OSS uses one national portal, one business registration number (NIB) and one business licensing (Business license and operational or commercial license). Business Licenses are issued based on commitments that must be fulfilled by business actors. The fulfillment is then completed by the Ministries or Institutions and local governments. The OSS system is used by all business actors in the form of business entities and individuals; micro, small, medium and large businesses; individual businesses / business entities both new and established before the OSS operationalization. Businesses with capital entirely within the country, or there is a composition of foreign capital. There are two types of business licenses issued through OSS, 
namely business licenses and commercial or operational licenses. OSS on behalf of institutions, ministries and provincial or district governments are responsible for (1) Registration process, (2) Issuance of business licenses (including sectoral business licenses and Trading Business licenses (SIUP), (3) Issuance of Commercial Permits (including the distribution permit and certification / license, when the process is doing online by the system if the requirements are met, while the duties of the ministries, institutions, capital investment and one-stop integrated services agency in Province and Regency encourage the fulfillment of commitment requirements and the applicant's compliance.

\subsection{Discussion}

The Capital Investment and One-Stop Integrated Service Agency in Bantul Regency is formed with the legal basis of Bantul Regency of Regional Regulation Number 12 Year 2016 and Bantul Regent of Regulation No. 123 Year 2016 and then, commences operations in January 2017. The policies are implemented with the issuance of Minister of Home Affairs Regulation No. 100 Year 2016 concerning the Guidelines Nomenclature of the Investment and One-Stop Integrated Services Agency. The regulation confirms that the nomenclature of licensing institutions for investment is in the form of the Investment and One-Stop Integrated Services with various types that adapt to regional conditions and capabilities. The Capital Investment and One-Stop Integrated Services Agency (DPMPT) of Bantul Regency provides 98 types of permits and non-permits consisting of: (1) Basic Licensing: 4 types of services, (2) Trade and industrial licensing: 13 types of services, (3) Business licensing and construction services: 3 types of services, (4) transportation licensing: 3 types of services, (5) Health Licensing: 53 types of services, (6) Licensing of foreign labor exchanges: 1 type of services, (7) Licensing for sale of alcoholic beverages: 2 types of services, (8) Fisheries Business licensing: 7 types of services, (9) Fisheries Business Licenses: 7 types, (10) Tourism Business Licensing: 13 types of service [10].

Business Licensing with the OSS system began to be implemented in June 2018, during a period of 6 months of the OSS implementation, it appeared several kinds of problems. Online Single Submission is a licensing service program by using an online system centrally. The knowledge of internet technology among the society is certainly not the same, so that it requires the role of the government to resolve. The Investment and One-Stop Integrated Services Agency of Bantul Regency lacks access to the server. In this regard, if there is a problem, it will be discussed in a chat group with managers at the central level so that the results are also not optimal. The employee of the Investment and One-Stop Integrated Services Agency in Bantul Regency even can solve the problem by borrowing accounts from applicants who might also be less ethical.

Another problem is that there are differences in the number of registrants who get a Registration Business Number with applicants who follow a commitment and compliance process in the Capital Investment and One-Stop Integrated Services Agency in Bantul Regency. It means that there are many applicants who do not continue the process of obtaining business licenses and commercial or operational permits after obtaining The Business Identification Number. This problem certainly requires awareness from the community, especially the permit applicants about the importance of fulfilling commitments in the licensing process so that there is no body who feel disturbed by the business being developed. The Capital Investment and One-Stop Integrated Services Agency in Bantul Regency has conducted socialization but the socialization itself has not been specific to the permit applicants who have not fulfilled the commitments so that it is less effective. 
The Business Identification Number is auto register or immediately approved by the OSS system once it meets the requirements such as filling in the name of the registrant, address, National Identity Number (Indonesian ID Card / Passport), and other data contained in the Company Registration Certificate (TDP), Trade Business License (SIUP), API, Customs Access and Expatriate Placement Plan (RPTKA). The Business Identification Number can be printed by the applicant itself and is valid as a single identity which replaces for the Company Registration Certificate (TDP), and Trade Business License. Besides getting the Business Identification Number as a single identity, the applicant also gets a Tax Identification Number (NPWP), Healthcare Security (BPJS Kesehatan), and the National Social Security (BPJS Tenaga Kerja) for those who do not have it.

The other problem is the emergence of clarification from other parties, especially the regulation of changes in the business licensing in this case that the Business Identification Number has not fulfilled the commitment to business permit approval to the loan bank application. It shows that the agreement of the Business Identification Number before the fulfillment of commitment can give rise to various types of conflict that must be minimalized.

\section{Conclusion}

The Investment and One Stop Integrated Service Agency processes the fulfillment of commitments or requirements for permits needed in the business permit approval process and OSS. The Lack of the number of applicants who continue the licensing process after obtaining the Business Identification Number needs to be followed up with the socialization of OSS licenses for multi stakeholders so that the community has a high awareness of the need to fulfill commitments for applicants for business licenses. The importance of environmental impact in the form of an operation to enforce the commitment of the business licenses applicant. Online Single Submission policy needs to be immediately followed up with the integration of information technology between ministries, provinces, and regions.

\section{References}

[1] S. Supardal, "Penerapan ICT dalam Pelayanan Publik di Kabupaten Bantul," Otoritas J. Ilmu Pemerintah., vol. 6, no. 2, pp. 120-134, 2016.

[2] Kominfo, "Inilah PP No. 24/2018 tentang Pelayanan Perizinan Berusaha Terintegrasi Secara Elektronik," 2018. [Online]. Available: https://kominfo.go.id/content/detail/13307/inilah-pp-no-242018-tentang-pelayananperizinan-berusaha-terintegrasi-secara-elektronik/0/berita. [Accessed: 29-Jan-2018].

[3] L. Moleong, Metodologi Penelitian Kualitatif. Bandung: PT. Remaja Rosdakarya, 2010.

[4] S. Arikunto, "Manajemen Penelitian Cet," PT. RinekaCipta, Jakarta, 1990.

[5] E. A. Purwanto, Implementasi Kebijakan Publik Konsep dan Aplikasinya di Indonesia, no. 1. 2012, 2012.

[6] B. Winarno, "Teori Kebijakan Publik," Yogyakarta PAU Stud. Sos. UGM, 1989.

[7] R. E. Indrajit, Electronic Goverment, Strategi Pembangunan dan Pengembangan Layanan Publik Berbasis Teknologi Digital. Yogyakarta: Andi Offset, 2002.

[8] R. E. Indrajit, Electronic Goverment. Yogyakarta: Andi Offset, 2006.

[9] E. Sosiawan, “A.,'Tantangan Dan Hambatan Dalam Implementasi E-Government Di 
Indonesia (Challenges and Obstacles in Implementing E-Government in Indonesia),", Natl. Proceeding e-Indonesia, ITB, Bandung, pp. 46-59, 2008.

[10] E. A. Sosiawan, Laporan Akuntabilitas DPMPT Kabupaten Bantul. Yogyakarta: DPMPT Kabupaten Bantul, 2015. 